\title{
Growth Performance of 'Granny Smith' and 'Fuji' Cultivars Grafted onto Dwarf Rootstocks: a Preliminary Study in Eastern Anatolia
}

\author{
Halil İbrahim OĞUZ', Teyar M TAŞ², Ferhat MURADOĞLU² \\ ${ }^{1}$ Adiyaman University, Agricultural Research Center, Adryaman, Turkey; hioguz64@gmail.com \\ ${ }^{2}$ Yüzüncü Yul University, Faculty of Agriculture, Van, Turkey
}

\begin{abstract}
This study was carried out to determine the growth performance of 'Granny Smith' and 'Fuji' apple varieties, which are widley grown in Turkey, grafted to dwarf rootstocks within their initial two years under continental ecological conditions of the Van Region in East Anatolia. In the first year, the vegetative characters of the cultivars were measured, whereas the yield and the growth rate were both determined in the second year. The yields of 'Granny Smith' and 'Fuji' varieties were 2.38 and $3.88 \mathrm{~kg}$, with average fruit weights of 173.71 $\mathrm{g}$ and $136.76 \mathrm{~g}$, respectively. The concentrations of soluble solids, an important quality attribute, were $11.2 \%$ and $12.9 \%$ for 'Granny Smith' and 'Fuji', respectively. Titratable acidity, which indicates the maturity of the fruit and specifies the market suitability, was found to be $0.37 \%$ in 'Granny Smith' and $0.52 \%$ in 'Fuji'. Although some properties differed between these cultivars, the firmness of both cultivars was the same, with a value of 6.6 libre. Although both varieties have a double sigmoid vegetative growth, 'Granny Smith”'s vegetative growth was relatively better than that of 'Fuji', whereas 'Fuji' had a higher productivity. However, for precise evaluation of yields, the period of economical production is required. Preliminary results of morphological, phenological, and pomological tests showed that the varieties 'Granny Smith' and 'Fuji' grafted onto dwarf rootstocks have a potential for increased production in the Van region of Eastern Turkey.
\end{abstract}

Keywords: Dwarf rootstock, 'Fuji, 'Granny Smith', Lake Van

\section{Introduction}

The global size of apple orchards is $5.6 \mathrm{~m} / \mathrm{ha}$, with a production of 57 million tons and average productivity of 100.601 tons/ha. China, USA, Turkey, France, and Iran are the leading apple producers, contributing $55 \%$ of the total production. Turkey, with a proportion of $4.4 \%$, ranks third in production, and its productivity $(230.203 \mathrm{~kg} / \mathrm{ha})$ is more than the global average productivity. However, it is still in the $13^{\text {th }}$ position in production, which is led by New Zealand with $380.473 \mathrm{~kg} / \mathrm{ha}$. The high yield in apple production is facilitated by cultivation of dwarf varieties, which lowers the maintenance costs due to pruning, harvesting, and applying pesticides and herbicides, in addition to increasing the nutrient uptake of roots (DPT, 2006). Moreover, dwarf apple trees come into bearing 2-3 years after planting, and therefore provide an income more rapidly than standard trees (Walsh et al., 1996). Thus, apple is a promising commercial crop, particularly in regions with low income and fragmented lands.

Apple orchard systems have undergone tremendous changes over the past 60 years; they have transitioned from traditional production systems established with large trees in wide spacing arrangements to high-density orchards with smaller closely spaced trees (Robinson, 2004). In Turkey, dwarf apple cultivation has become widespread over the past two decades and has become an important fruit in the country, with a production of approximately $2,550,000$ tons/year, which is a $22 \%$ increase since the 1980s (FAO, 2007).

'Granny Smith' and 'Fuji' are common apple varieties in Turkey. The former has an average fruit weight of 160 g (Karlıdağ et al., 2007), whereas the latter has a weight of $220 \mathrm{~g}$ (Motosugi et al., 1995). Although seasonal variations and crop-management strategies cause great variations in the soluble solid concentration (SSC) in apple, the average concentration varies from $17 \%$ to $19 \%$ in 'Fuji' (Kupferman, 1992) and from $11 \%$ to $13 \%$ for 'Granny Smith' (Saftner et al., 2005).

Apple can be cultivated in several regions of Turkey; however, research on the potential for dwarf apple production in Eastern Anatolia, which may provide highincome opportunities to locals, is insufficient (Küden, 1998). The Eastern Anatolia region of Turkey, particularly Lake Van-with its favorable climatic (cold weather, high intensity of sunlight) and soil (high organic matter and cation-exchange capacity) conditions (Akça et al., 2008) is a notable zone for production of dwarf apples. Traditional fruit cultivation is common in the region; however, due to modern cultivation techniques, the productivity and production are low (Oğuz and Aşkın, 1993). Because the goal of modern high-density orchard systems is to achieve high yield at early tree age (Yıldırım and Kankaya, 2004), studies on dwarf cultivars in the Lake Van Region is crucial for 
increasing cropping efficiency. The most important reason for choosing these cultivars is their intense growth values all over the world, and especially in Turkey, in the past few years. In this study, we determine the properties indicating the growth performance of both 'Granny Smith' and 'Fuji' cultivars grafted onto dwarf rootstocks in the Van region.

\section{Materials and methods}

This study was undertaken in the Lake Van region of Eastern Turkey (Fig. 1) in 2007-2008 on cultivars of 'Granny Smith' and 'Fuji' grafted onto M26 and M9 rootstocks, respectively. The study site has an altitude of 1675 $\mathrm{m}$ a.s.l., with $377 \mathrm{~mm}$ precipitation and a continental cli-

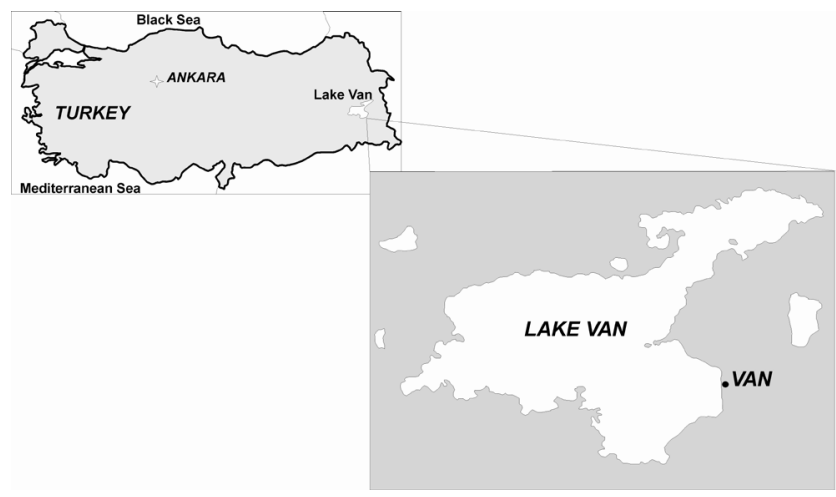

Fig. 1. Location of the study site

mate.

The saplings were planted in the spring of 2007 . In the first year, the vegetative growth parameters of 30 trees were determined by measuring sapling height, stem diameter, and shoot length at 15-day intervals. The date of blooming was based on the flowering of 70-80\% of the total flower buds (Oğuz and Aşkın, 1993).

The height of the sapling is the distance from the budding point to the highest point of the sapling. The stem diameter is measured $10 \mathrm{~cm}$ above the bud eye by 0.01 $\mathrm{cm}$ sensitive calipers. The shoot length of each tree is measured at three shoots located at different sides of the tree (Robinson, 2004).
The measurements in the second year, undertaken at 30 trees of each cultivar, involved determination of the start of blooming, full blooming, and production, whereas the fruit properties of diameter, length, SSC, titratable acidity (TA), and pulp hardness (PH) are determined for 10 trees of each variety (Jolly and North, 1982)

The cultivars are compared by analysis of variance, and the means are differentiated using the Duncan's multiplerange tests for each variety.

\section{Results}

The stem diameter of 'Granny Smith' increased from $12.57 \mathrm{~mm}$ to $21.35 \mathrm{~mm}$ during the first year, whereas that of the 'Fuji' cultivar increased from $11.65 \mathrm{~mm}$ to 19.66 $\mathrm{mm}$ within the same period (Tab. 1 ). Both cultivars had a regular growth rate until the $15^{\text {th }}$ of July 2007; the development halted from the $15^{\text {th }}$ of July to the $30^{\text {th }}$ of July 2007 and resumed after $30^{\text {th }}$ of July.

The stem growth for both cultivars in the second year showed a sigmoid growth, with a relatively slow phase in Early Spring, an increase in Mid Summer, and a retarded phase in the early Fall of 2008 (Tab. 2); with a total growth of $39.38 \mathrm{~cm}$ for 'Granny Smith' and $36.42 \mathrm{~cm}$ for 'Fuji'. The growth of both cultivars showed a linear development, with mean increases of $43.75 \mathrm{~cm}$ for 'Granny Smith' (from $79.51 \mathrm{~cm}$ to $123.26 \mathrm{~cm}$ ) and $40.34 \mathrm{~cm}$ for 'Fuji' (from $73.32 \mathrm{~cm}$ at the initial stage to 113.66 at the end of the season) in 2007 (Tab. 3).

The results obtained in this study are in accordance with the studies undertaken by Kadan and Yarılgaç (2005), who determined the sapling height as 89.17 and 109.75 $\mathrm{cm}$ for other cultivars in Eastern Anatolia. Tekintaş et al. (1999) found the sapling height for local varieties in the Lake Van region in the range of 60-84 cm. Other authors, however, report significant differences in the growth rates for 'S. Delicious,' 'G. Delicious', and 'S. Spur Golden' saplings, with heights of $181.3,190.4$, and $200.5 \mathrm{~cm}$, respectively, in the mild climates of Bursa region, Western Turkey (Soylu and Başyiğit, 1991).

In 2008, the growth rate of the trees was relatively high, particularly in June and July (Tab. 4). 'Granny Smith'

Tab. 1. Comparison of cultivars in terms of their body diameter in 2007

\begin{tabular}{|c|c|c|c|c|c|c|c|}
\hline \multirow{3}{*}{ Date of measurement } & \multicolumn{2}{|c|}{ Cultivars } & \multirow{2}{*}{\multicolumn{2}{|c|}{ 'Granny Smith’ }} & \multirow{2}{*}{\multicolumn{2}{|c|}{ 'Fuji' }} & \multirow{3}{*}{$\mathrm{P}$} \\
\hline & \multirow{2}{*}{$\begin{array}{c}\text { 'Granny Smith' } \\
\text { AVRG } \pm \text { SE }\end{array}$} & \multirow{2}{*}{$\begin{array}{c}\text { 'Fuji' } \\
A V R G \pm S E\end{array}$} & & & & & \\
\hline & & & least & most & least & most & \\
\hline 30.05 .2007 & $12.57 \pm 0.24 \mathrm{a}$ & $11.65 \pm 0.33 b$ & 7.20 & 18.5 & 7.00 & 17.20 & * \\
\hline 15.06 .2007 & $13.66 \pm 0.25 \mathrm{a}$ & $12.05 \pm 0.32 b$ & 8.00 & 20.00 & 7.20 & 18.00 & *** \\
\hline 30.06 .2007 & $14.88 \pm 0.27 a$ & $13.44 \pm 0.35 b$ & 8.80 & 23.30 & 8.00 & 20.10 & ** \\
\hline 15.07 .2007 & $16.02 \pm 0.26 a$ & $14.61 \pm 0.35 b$ & 10.10 & 23.90 & 9.90 & 20.90 & ** \\
\hline 29.07 .2007 & $16.02 \pm 0.26 a$ & $14.61 \pm 0.35 b$ & 10.10 & 23.90 & 9.90 & 20.90 & ** \\
\hline 15.08 .2007 & $18.66 \pm 0.27 \mathrm{a}$ & $17.22 \pm 0.35 b$ & 13.40 & 26.00 & 12.30 & 23.70 & ** \\
\hline 29.08 .2007 & $19.96 \pm 0.27 a$ & $18.46 \pm 0.35 b$ & 14.20 & 27.30 & 13.50 & 25.50 & ** \\
\hline 14.09 .2007 & $21.35 \pm 0.31 \mathrm{a}$ & $19.66 \pm 0.40 b$ & 15.30 & 28.50 & 14.60 & 27.30 & ** \\
\hline
\end{tabular}


Tab. 2. Comparison of cultivars in terms of their body diameter in 2008

\begin{tabular}{|c|c|c|c|c|c|c|c|}
\hline \multirow{3}{*}{ Date of measurement } & \multicolumn{2}{|c|}{ cultivars } & \multirow{2}{*}{\multicolumn{2}{|c|}{ 'Granny Smith’ }} & \multirow{2}{*}{\multicolumn{2}{|c|}{ 'Fuji' }} & \multirow{3}{*}{$\mathrm{P}$} \\
\hline & \multirow{2}{*}{$\begin{array}{c}\text { 'Granny Smith' } \\
\text { AVRG } \pm \text { SE }\end{array}$} & \multirow{2}{*}{$\begin{array}{c}\text { 'Fuji' } \\
\text { AVRG } \pm S E\end{array}$} & & & & & \\
\hline & & & least & most & least & most & \\
\hline 30.05 .2008 & $22.72 \pm 0.32 \mathrm{a}$ & $21.01 \pm 0.42 b$ & 7.20 & 18.5 & 7.00 & 17.20 & * \\
\hline 15.06 .2008 & $24.88 \pm 0.35 a$ & $23.01 \pm 0.46 b$ & 8.00 & 20.00 & 7.20 & 18.00 & * \\
\hline 30.06 .2008 & $27.37 \pm 0.38 \mathrm{a}$ & $25.31 \pm 0.51 b$ & 8.80 & 23.30 & 8.00 & 20.10 & * \\
\hline 15.07 .2008 & $30.17 \pm 0.42 \mathrm{a}$ & $27.90 \pm 0.56 b$ & 10.10 & 23.90 & 9.90 & 20.90 & * \\
\hline 29.07 .2008 & $34.98 \pm 0.49 a$ & $32.36 \pm 0.65 b$ & 10.10 & 23.90 & 9.90 & 20.90 & * \\
\hline 15.08 .2008 & $36.54 \pm 0.51 \mathrm{a}$ & $33.80 \pm 0.68 b$ & 13.40 & 26.00 & 12.30 & 23.70 & * \\
\hline 29.08 .2008 & $38.07 \pm 0.53 \mathrm{a}$ & $35.21 \pm 0.71 b$ & 14.20 & 27.30 & 13.50 & 25.50 & * \\
\hline 14.09 .2008 & $39.38 \pm 0.55 \mathrm{a}$ & $36.42 \pm 0.73 b$ & 15.30 & 28.50 & 14.60 & 27.30 & * \\
\hline
\end{tabular}

${ }^{*} \mathrm{P}<0.05 ;{ }^{* *} \mathrm{P}<0.01 ;{ }^{* * *} \mathrm{P}<0.001$ (The difference between the letters in each line is vital)

Tab. 3. Comparison of cultivars in terms of their height in 2007

\begin{tabular}{|c|c|c|c|c|c|c|c|}
\hline \multirow{3}{*}{ Date of measurement } & \multicolumn{2}{|c|}{ cultivars } & \multirow{2}{*}{\multicolumn{2}{|c|}{ 'Granny Smith’ }} & \multirow{2}{*}{\multicolumn{2}{|c|}{ 'Fuji' }} & \multirow{3}{*}{$\mathrm{P}$} \\
\hline & \multirow{2}{*}{$\begin{array}{c}\text { 'Granny Smith' } \\
\text { AVRG } \pm \text { SE }\end{array}$} & \multirow{2}{*}{$\begin{array}{c}\text { 'Fuji' } \\
\text { AVRG } \pm S E\end{array}$} & & & & & \\
\hline & & & least & most & least & most & \\
\hline 30.05 .2007 & $79.51 \pm 0.83 a$ & $73.32 \pm 1.14 b$ & 56.00 & 103.00 & 56.00 & 93.00 & $* * *$ \\
\hline 15.06 .2007 & $86.01 \pm 0.90 \mathrm{a}$ & $79.36 \pm 1.22 b$ & 61.00 & 111.00 & 61.00 & 100.00 & $* * *$ \\
\hline 30.06 .2007 & $92.74 \pm 0.97 \mathrm{a}$ & $85.48 \pm 1.33 b$ & 65.00 & 120.00 & 65.00 & 108.00 & *** \\
\hline 15.07 .2007 & $99.68 \pm 1.04 a$ & $91.91 \pm 1.42 b$ & 70.00 & 129.00 & 70.00 & 116.00 & *** \\
\hline 29.07 .2007 & $105.85 \pm 1.11 \mathrm{a}$ & $97.63 \pm 1.51 b$ & 75.00 & 137.00 & 75.00 & 123.00 & *** \\
\hline 15.08 .2007 & $112.12 \pm 1.17 \mathrm{a}$ & $03.41 \pm 1.61 b$ & 79.00 & 145.00 & 79.00 & 130.00 & *** \\
\hline 29.08 .2007 & $118.35 \pm 1.24 a$ & $09.14 \pm 1.70 b$ & 83.00 & 153.00 & 83.00 & 138.00 & *** \\
\hline 14.09 .2007 & $123.26 \pm 1.29 \mathrm{a}$ & $13.66 \pm 1.76 b$ & 87.00 & 159.00 & 87.00 & 143.00 & $* * *$ \\
\hline
\end{tabular}

${ }^{*} \mathrm{P}<0.05 ;{ }^{* *} \mathrm{P}<0.01 ;{ }^{* * *} \mathrm{P}<0.001$ (The difference between the letters in each line is vital)

Tab. 4 Comparison of cultivars in terms of their heights in 2008

\begin{tabular}{|c|c|c|c|c|c|c|c|}
\hline \multirow{3}{*}{ Date of measurement } & \multicolumn{2}{|c|}{ Cultivars } & \multirow{2}{*}{\multicolumn{2}{|c|}{ 'Granny Smith' }} & \multirow{2}{*}{\multicolumn{2}{|c|}{ 'Fuji' }} & \multirow{3}{*}{$\mathrm{P}$} \\
\hline & \multirow{2}{*}{$\begin{array}{c}\text { 'Granny Smith' } \\
\text { AVRG } \pm \text { SE }\end{array}$} & \multirow{2}{*}{$\frac{\text { 'Fuji' }}{\text { AVRG } \pm S E}$} & & & & & \\
\hline & & & least & most & least & most & \\
\hline 30.05 .2008 & $131.41 \pm 1.37$ & $121.27 \pm 1.88$ & 93.00 & 170.00 & 93.00 & 153.00 & *** \\
\hline 15.06 .2008 & $141.90 \pm 1.48$ & $130.84 \pm 2.03$ & 100.00 & 183.00 & 100.00 & 165.00 & *** \\
\hline 30.06 .2008 & $155.42 \pm 1.62$ & $143.38 \pm 2.22$ & 110.00 & 201.00 & 110.00 & 181.00 & $* * *$ \\
\hline 15.07 .2008 & $170.21 \pm 1.78$ & $156.96 \pm 2.44$ & 120.00 & 220.00 & 120.00 & 198.00 & *** \\
\hline 29.07 .2008 & $181.60 \pm 1.90$ & $167.43 \pm 2.60$ & 128.00 & 235.00 & 128.00 & 211.00 & *** \\
\hline 15.08 .2008 & $189.67 \pm 1.98$ & $174.89 \pm 2.72$ & 134.00 & 245.00 & 134.00 & 221.00 & *** \\
\hline 29.08 .2008 & $197.59 \pm 2.06$ & $182.14 \pm 2.84$ & 139.00 & 255.00 & 139.00 & 230.00 & *** \\
\hline 14.09 .2008 & $204.39 \pm 2.13$ & $188.48 \pm 2.93$ & 144.00 & 264.00 & 144.00 & 238.00 & *** \\
\hline
\end{tabular}

${ }^{*} \mathrm{P}<0.05 ;{ }^{* *} \mathrm{P}<0.01 ;{ }^{* * *} \mathrm{P}<0.001$ (The difference between the letters in each line is vital)

Tab. 5. Comparison of cultivars in terms of their shoot lengths in 2007

\begin{tabular}{|c|c|c|c|c|c|c|c|}
\hline \multirow{3}{*}{ Date of measurement } & \multicolumn{2}{|c|}{ Cultivars } & \multirow{2}{*}{\multicolumn{2}{|c|}{ 'Granny Smith’ }} & \multirow{2}{*}{\multicolumn{2}{|c|}{ 'Fuji’ }} & \multirow{3}{*}{$\mathrm{P}$} \\
\hline & \multirow{2}{*}{$\begin{array}{c}\text { 'Granny Smith' } \\
\text { AVRG } \pm \text { SE } \\
\end{array}$} & \multirow{2}{*}{$\frac{\text { 'Fuji' }}{A V R G \pm S E}$} & & & & & \\
\hline & & & least & most & least & most & \\
\hline 30.05 .2007 & $6.18 \pm 0.24 a$ & $5.58 \pm 0.15 \mathrm{a}$ & 3.57 & 30.05 & 2.67 & 8.10 & $\mathrm{~ns}$ \\
\hline 15.06 .2007 & $6.64 \pm 0.14 \mathrm{a}$ & $6.12 \pm 0.17 b$ & 3.93 & 15.06 & 2.97 & 8.87 & * \\
\hline 30.06 .2007 & $6.77 \pm 0.24 a$ & $6.75 \pm 0.19 \mathrm{a}$ & 3.93 & 30.06 & 3.23 & 9.80 & ns \\
\hline 15.07 .2007 & $7.67 \pm 0.15 \mathrm{a}$ & $7.34 \pm 0.20 \mathrm{a}$ & 4.53 & 15.07 & 3.53 & 10.67 & ns \\
\hline 29.07 .2007 & $8.30 \pm 0.24 a$ & $7.83 \pm 0.22 \mathrm{a}$ & 4.83 & 30.07 & 3.77 & 11.37 & ns \\
\hline 15.08 .2007 & $8.52 \pm 0.16 \mathrm{a}$ & $8.18 \pm 0.23 a$ & 5.03 & 15.08 & 3.93 & 11.90 & ns \\
\hline 29.08 .2005 & $8.75 \pm 0.16 a$ & $8.40 \pm 0.23 a$ & 5.20 & 15.09 & 4.07 & 12.20 & ns \\
\hline 14.9 .2007 & $8.45 \pm 0.15 \mathrm{a}$ & $8.92 \pm 0.25 \mathrm{a}$ & 5.02 & 30.05 & 4.30 & 12.90 & ns \\
\hline
\end{tabular}

${ }^{*} \mathrm{P}<0.05 ;{ }^{* *} \mathrm{P}<0.01 ;{ }^{* * *} \mathrm{P}<0.001 ;$ ns: non significant (The difference between the letters in each line is vital) 
reached a height of $204.39 \mathrm{~cm}$ and 'Fuji', $188.48 \mathrm{~cm}$ (Tab. 4 ). The shoot lengths of 'Granny Smith' and 'Fuji' were measured at 15-day intervals for determining the annual and the seasonal growth rates. 'Granny Smith' had a mean shoot lengths of 6.18 and $8.45 \mathrm{~cm}$, when measured on the $30^{\text {th }}$ of May 2007 and in early fall, respectively (Tab. 5). The shoot length of 'Fuji' reached $8.45 \mathrm{~cm}$ from an initial length of $6.18 \mathrm{~cm}$ (Tab. 5).

In 2008, 'Granny Smith' showed relatively slow shoot development until the $15^{\text {th }}$ of June, which accelerated thereafter; on the contrary, for the 'Fuji' cultivar, shoot development was the maximum between the $15^{\text {th }}$ and $30^{\text {th }}$ of July (Tab. 6). The seasonal differences in the shoot growth between the two years are most probably caused by climatic differences.

The major advantage of the dwarf rootstock is the early setting of fruit in the grafted cultivar (Küden et al., 1993). In the present study, the cultivars bore fruits in the second year, yielding $2.37 \mathrm{~kg} /$ tree for 'Granny Smith' and $3.88 \mathrm{~kg} /$ tree for 'Fuji' (Tab. 7), with average fruit weights of 173.71 and $139.76 \mathrm{~g}$ for the two cultivars, respectively (Tab. 8).

The mean pomological characteristics of the cultivars were given in Tab. 9. For 'Granny Smith' and 'Fuji', the fruit diameters were 75.8 and $63.5 \mathrm{~mm}$, and the average lengths were 63.6 and 57.1, respectively (Tab. 1). The properties of the fruits were similar to the previous findings of Kaşka and Küden (1994), and Kankaya and Özyiğit (1998). The $\mathrm{pH}$ for both cultivars was $6.6 \mathrm{lb}$, and the SSC were $11.2 \%$ for 'Granny Smith' and $12.9 \%$ for 'Fuji' (Tab. 9).

The TA contents were 37\% and 52\% for 'Granny Smith' and 'Fuji', respectively, which are within the standard values of Cripps et al. (1993), Oğuz and Aşkın (1993), and Karlidağ et al. (2007).

Blooming of both cultivars was found to occur close to each other. The first blooming date for 'Granny Smith' was $13^{\text {th }}$ of May 2008, and full blooming was achieved within 7 days. The 'Fuji' cultivar first effloresced on the $12^{\text {th }}$ of May 2008 and, similar to 'Granny Smith', full efflorescence was reached on the $19^{\text {th }}$ of May 2008.

Tab. 6. Comparison of cultivars in terms of their shoot lengths in 2008

\begin{tabular}{|c|c|c|c|c|c|c|c|}
\hline \multirow[t]{3}{*}{ Period } & \multicolumn{2}{|c|}{ Cultivars } & \multirow{2}{*}{\multicolumn{2}{|c|}{ 'Granny Smith' }} & \multirow{2}{*}{\multicolumn{2}{|c|}{ 'Fuji' }} & \multirow{3}{*}{$\mathrm{P}$} \\
\hline & \multirow{2}{*}{$\begin{array}{c}\text { 'Granny Smith' } \\
\text { AVRG } \pm \text { SE }\end{array}$} & \multirow{2}{*}{$\begin{array}{c}\text { 'Fuji' } \\
\text { AVRG } \pm S E\end{array}$} & & & & & \\
\hline & & & least & most & least & most & \\
\hline 30.05 .2008 & $4.06 \pm 0.10 \mathrm{a}$ & $5.14 \pm 0.16 b$ & 3.74 & 8.89 & 3.20 & 8.50 & $* * *$ \\
\hline 15.06 .2008 & $4.27 \pm 0.09 b$ & $5.62 \pm 0.18 a$ & 3.31 & 7.63 & 3.07 & 9.30 & * \\
\hline 30.06 .2008 & $5.11 \pm 0.06 b$ & $6.20 \pm 0.20 \mathrm{a}$ & 2.69 & 7.45 & 3.37 & 10.27 & ** \\
\hline 15.07 .200 & $6.15 \pm 0.08 b$ & $6.74 \pm 0.22 \mathrm{a}$ & 3.25 & 7.06 & 3.67 & 11.20 & *** \\
\hline 29.07 .2008 & $6.84 \pm 0.08 b$ & $8.16 \pm 0.23 a$ & 3.08 & 6.97 & 3.90 & 11.87 & ** \\
\hline 15.08 .2008 & $7.70 \pm 0.07 \mathrm{~b}$ & $8.40 \pm 0.24 a$ & 3.01 & 6.93 & 4.03 & 12.27 & $* * *$ \\
\hline 29082008 & $7.90 \pm 0.08 b$ & $8.72 \pm 0.25 a$ & 3.11 & 7.76 & 4.20 & 12.80 & $* * *$ \\
\hline 14.9 .2008 & $8.81 \pm 0.08 \mathrm{~b}$ & $9.13 \pm 0.26 \mathrm{a}$ & 3.07 & 5.84 & 4.43 & 13.37 & $* * *$ \\
\hline
\end{tabular}

${ }^{*} \mathrm{P}<0.05 ;{ }^{* *} \mathrm{P}<0.01 ;{ }^{* * *} \mathrm{P}<0.001$ (The difference between the letters in each line is vital)

Tab. 7. Some pomological properties of the 'Granny Smith' cultivar in 2008

\begin{tabular}{ccccccc}
\hline $\begin{array}{c}\text { Fruit Weight } \\
(\mathrm{gr})\end{array}$ & $\begin{array}{c}\text { Fruit diameter } \\
(\mathrm{mm})\end{array}$ & Fruit Length $(\mathrm{mm})$ & TA & SSC $(\%)$ & $\begin{array}{c}\text { Productivity } \\
\text { tree } / \mathrm{kg}\end{array}$ & PH (lb) \\
\hline 157 & 71.52 & 57.42 & 0.34 & 10.05 & 2.33 & 5.80 \\
159 & 74.59 & 56.99 & 0.35 & 11.05 & 2.45 & 6.00 \\
167 & 75.30 & 62.73 & 0.35 & 11.05 & 2.21 & 6.50 \\
172 & 76.66 & 64.41 & 0.38 & 11.05 & 2.22 & 6.60 \\
178 & 76.85 & 66.92 & 0.40 & 11.09 & 2.33 & 7.10 \\
185 & 77.07 & 67.55 & 0.40 & 12.00 & 2.08 & 7.10 \\
198 & 78.61 & 68.95 & 0.40 & 12.01 & 2.03 & 7.30 \\
\hline
\end{tabular}

Tab. 8. Some pomological properties of the 'Fuji' cultivar in 2008

\begin{tabular}{ccccccc}
\hline Fruit Weight $(\mathrm{gr})$ & $\begin{array}{c}\text { Fruit diameter } \\
(\mathrm{mm})\end{array}$ & $\begin{array}{c}\text { Fruit Length } \\
(\mathrm{mm})\end{array}$ & TA & SSC (\%) & $\begin{array}{c}\text { Productivity } \\
\text { tree } / \mathrm{kg}\end{array}$ & PH (lb) \\
\hline 107.00 & 55.18 & 52.08 & 0.40 & 11.05 & 3.666 & 5.60 \\
112.05 & 61.09 & 52.12 & 0.40 & 12.05 & 3.956 & 5.70 \\
117.00 & 62.00 & 54.39 & 0.41 & 12.08 & 3.646 & 6.05 \\
117.09 & 62.43 & 54.62 & 0.51 & 13.00 & 3.956 & 6.60 \\
139.07 & 63.09 & 57.74 & 0.53 & 14.00 & 3.611 & 7.00 \\
187.07 & 66.66 & 64.25 & 0.69 & 14.04 & 4.105 & 7.60 \\
199.05 & 74.37 & 64.26 & 0.70 & 14.05 & 4.255 & 7.70 \\
\hline
\end{tabular}


Tab. 9. Some fruit characteristics of 'Granny Smith' and 'Fuji' cultivars in 2008

\begin{tabular}{cccccccc}
\hline Cultivar & $\begin{array}{c}\text { Fruit diameter } \\
(\mathrm{mm})\end{array}$ & $\begin{array}{c}\text { Fruit Length } \\
(\mathrm{mm})\end{array}$ & $\begin{array}{c}\text { TA } \\
(\%)\end{array}$ & $\begin{array}{c}\text { SSC } \\
(\%)\end{array}$ & $\begin{array}{c}\text { PH } \\
(\mathrm{lib})\end{array}$ & First Blooming Date & Full Blooming Date \\
\hline 'Granny Smith' & 75.8 & 63.6 & 0.37 & 11.2 & 6.6 & 13.05 .2008 & 21.05 .2008 \\
'Fuji & 63.5 & 57.1 & 0.52 & 12.9 & 6.6 & 12.05 .2008 & 19.05 .2008 \\
\hline
\end{tabular}

\section{Discussion}

The preference for grafting cultivars onto dwarf rootstocks for apple cultivation is aimed at the production of more flowers and fruits. In addition, saplings grafted onto dwarf rootstocks produce fruits approximately in the second year, which is 4 or 5 years earlier than the original rootstock. The annual production per hectare in the $5^{\text {th }}$ year is 250 tons, which is five or six times higher than that in the traditional varieties. Thus, cultivation of dwarf apples has several benefits for producers. Turkey being the original source of apple has sites suitable for apple production; however, studies in Eastern Turkey, particularly in the Lake Van region, is not sufficient. Our preliminary study showed that 'Granny Smith' and 'Fuji' cultivars, when grafted onto M9 and M26 rootstocks, respectively, have high economic potential in the Van region, in spite of the region having harsh topographic and climatic conditions. Shifting from traditional varieties to dwarf ones may also increase the income of local farmers, who are struggling due to low incomes from traditional cultivars. Based on all the vegetative growth phases, we can conclude that 'Granny Smith"s growth rate is relatively higher than that of 'Fuji', whereas 'Fuji"s production is better than that of 'Granny Smith'. However, further studies are required for the precise evaluation of the productivity of both varieties when the trees are in the full-production stage.

\section{References}

Akça E, Çimrin KM, Ryan J, Nagano T, Topaksu M, Kapur S (2008). Differentiating the natural and man-made terraces of Lake Van, Eastern Anatolia, utilizing earth science methods. Lakes \& Reservoirs Research and Management 13:83-93.

Cripps JEL, Richards LA, Mairata AM (1993). 'Pink Lady'apple. HortScience 28:1057.

DPT (2006). Agricultural Structure and Production. State Planing Office Publications of the Prime Ministry of Turkey. SIS, Ankara

FAO (2007). Statistical Database of FAO in 2007. www.fao. org.

Jolly PR, North M (1982). Goldsmith- New apple selection in Elgin- Promising as green cultivar to ripen before 'Granny Smith'. Plant Breeding 52:1

Kaçka N, Küden A (1994). Fruit yield and cultures of three important apple cultivars grafted on some clonal and seedling rootstock. University of Cukurova, Faculty of Agr J 8(2):179-188

Kadan H, Yarılgaç T (2005). Stagnant T- budding of Apple and Pear Research on Reproduction In Ecological Conditions Van. Yuzuncu Yil University, J Agric Sci) 15(2):167-176
Kankaya A, Özyiğit S (1998). Product, quality and plant production of some apple cultivars grafted on M9 in Region of Egridir. Aegean Region I. Agriculture in October, Tokat 247-256.

Karlıdağ H, Eşitken A, Turan M, Şahin F (2007). Effects of root inoculation of plant growth promoting rhizobacteria (PGPR) on yield, growth and nutrient element contents of leaves of apple. Scientia Horticulturae 114:16-20.

Küden AB, Küden A, Kagka N (1993). Adaptations of some selected almonds to Mediterranean region of Turkey. I International Congress on Almond. Acta Hort 373:83-89.

Küden A (1998). Horticultural Research in Turkey. The World Conference on Horticultural Research (WCHR). 17-20 June Bologna Italy.

Kupferman E (1992). Maturity and Storage of Apple Varieties New to Washington State. Tree Fruit Postharvest Journal 3(1):9-16.

Motosugi H, Gao YP, Sugiura A (1995). Rootstock Effects on Fruit Quality of 'Fuji' Apples Grown with Ammonium or Nitrate Nitrogen in Sand Culture. Scientia Horticulture 61:205-214.

Oğuz HI, Aşkın MA (1993). Investigations on morphological and pomological characteristics of local apple cultivars grown in Ercis (MSc. Thesis) Yuzuncu Y1l University, Faculty of Agr J 3(1-2):281-298.

Robinson T (2004). Recent advances and future directions in Orchard Planting Systems. Acta Hort 732:367-381.

Saftner RA, Abbott JA, Bhagwat AA, Vinyard BT (2005). Quality Measurement of Intact and Fresh-cut Slices of 'Fuji', 'Granny Smith', Pink Lady, and Gold Rush Apples. J of Food Science 70:317-324.

Soylu A, Başyiğit H(1991). The growth, branching characteristics some of fruit sampling grown in Bursa Kestel region Turkey $1^{\text {st }}$ Arboriculture Symposium 26-28 October 1987, Tokat, p. 247-256.

Tekintaş FE, Yarılgaç T, İslam A (1999). Important local varieties of apple rootstocks grown in Van from seedling development; status examination. National Horticulture Congress, Turkey III, p. 634-638.

Walsh BD, Salmins S, Buszard DJ, MacKenzie AF (1996) Impact of soil management systems on organic dwarf apple orchards and soil aggregate stability, bulk density, temperature and water content. Canadian Journal of Soil Science 76:203209.

Yildirım FA, Kankaya A (2004). The Spontaneous Growth and Lateral Branch Habit of New Apple Cultivars in Nursery. International Journal of Agriculture and Biology 6:492494. 